\title{
SOURCES AND
}

\section{ABBREVIATIONS}

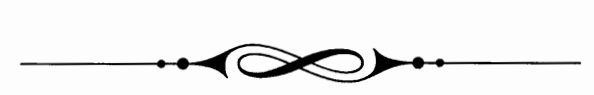

AA

private archive of Vasilii Azhaev

Amurlag

Corrective Labor Camps of the Amur

BAM

Baikal-Amur Main Line

BRIZ

Bureau of Rationalization and Invention

Chekist

ChK

employee of the $\mathrm{ChK}$

see VChK

Dal'krai

Far Eastern Administrative Region

Dal'neftekombinat

DV

Far Eastern Industrial Complex of the Oil Industry

EPRON

Far East

GAKhK

GARF

Expedition of Underwater Work for Special Purposes

State Archives of the Khabarovsk Administrative Region

State Archives of the Russian Federation

Glavlit

Main Administration of Affairs for Literature and

Publishing

gorkom

city committee

GULAG

Main Administration of Camps

GULZhDS

Main Administration of Railway Construction Camps

GUZhDS

Main Administration of Railway Construction

ITL

Corrective Labor Camp

$K L E$

Short Literary Encyclopaedia

Komsomol

Communist Youth League

kraikom

regional committee

KVCh

Cultural-Educational Unit

KVO

Cultural and Educational Department

litaktiv

active members of the Soviet Writers' Union

MGB

Ministry of State Security

MUR

Moscow Criminal Investigation Department 


\begin{tabular}{|c|c|}
\hline MVD & Ministry of Internal Affairs \\
\hline narkom & people's commissar \\
\hline Nizhne-Amurlag & Corrective Labor Camps of the Lower Amur \\
\hline NKVD & People's Commissariat of Internal Affairs \\
\hline obkom & oblast' (regional, provincial) committee \\
\hline OGIZ & United State Publishing House \\
\hline OGPU & United Main Political Administration \\
\hline OKDVA & Special Red-Bannered Far Eastern Army \\
\hline OLP & separate camp subsector \\
\hline raikom & district committee \\
\hline RAPP & Russian Association of Proletarian Writers \\
\hline RGALI & Russian State Archive of Literature and Art \\
\hline RGVA & Russian State Military Archives \\
\hline RKKA & Workers' and Peasants' Red Army \\
\hline RSFSR & Russian Soviet Federal Socialist Republic \\
\hline RTsKhIDNI & $\begin{array}{l}\text { Russian Center for the Conservation and Study of } \\
\text { Documents of Recent History }\end{array}$ \\
\hline Sovnarkom & Council of People's Commissars \\
\hline TsBRIZ & Central Bureau of Rationalization and Invention \\
\hline TsK & Central Committee \\
\hline UFSB & Administration of the Federal Service of Security \\
\hline UITLK & Administration of Corrective Labor Camps and Colonies \\
\hline UVD & Administration of Internal Affairs \\
\hline UZhDS & Department of Railway Construction \\
\hline VChK & $\begin{array}{l}\text { All-Russian Extraordinary Commission Combating } \\
\text { Counterrevolution, Sabotage, and Speculation }\end{array}$ \\
\hline VLKSM & All-Union Leninist Communist Youth League \\
\hline $\mathrm{VKP}(\mathrm{b})$ & All-Union Communist Party (of the Bolsheviks) \\
\hline VOKhR & Militarized Guard at Places of Confinement \\
\hline Zaporozhstroi & Zaporozh'e Industrial Complex \\
\hline$z e k$ & prisoner (from $z / k$, for zakliuchennyi) \\
\hline ZhDSU & Administration of Railway Construction \\
\hline
\end{tabular}

